\title{
The fall of a symbol? A high predation rate by the introduced horseshoe whip snake Hemorrhois hippocrepis paints a bleak future for the endemic Ibiza wall lizard Podarcis pityusensis
}

\author{
Arlo Hinckley ${ }^{1} \&$ Elba Montes $^{2} \&$ Enrique Ayllón $^{3} \&$ Juan M Pleguezuelos $^{4}$ \\ Received: 27 June 2016 / Revised: 28 August 2016 / Accepted: 30 November 2016 \# Springer- \\ Verlag Berlin Heidelberg 2016 \\ 1Arlo Hinckley arlohinckley@hotmail.com \\ 2Elba Montes elba.montes@conselldeivissa.es \\ 3Enrique Ayllón enrique.ayllon@herpetologica.org \\ 4Juan M Pleguezuelos juanple@ugr.es \\ 1Estación Biológica de Doñana (EBD-CSIC), Conservation and Evolutionary Genetics Group, \\ Av. Americo Vespucio s/n, 41092 Sevilla, Spain \\ 2Department of Environment, Ibiza Island Council, Av. España, 49, E-07800 Ibiza, Spain \\ 3Asociación Herpetológica Española, PO 191, E-28911 Leganés Madrid, Spain \\ 4Departamento de Zoología, Facultad de Ciencias, Universidad de Granada, E-18071 Granada, \\ Spain
}

\begin{abstract}
Invasive species currently account for a major threat to global biodiversity, and island ecosystems are among the most vulnerable, because of the frequency and success of spe- cies introductions on islands. Within Mediterranean islands, reptiles not only are frequently introduced species but are also among the most threatened because of these introductions. The Balearic archipelago is a good example of this, since only two of its current 16 species of reptiles are native. Thirteen years ago, the snake Hemorrhois hippocrepis was introduced by cargo in Ibiza island, and it is in expansion. Individuals obtain- ed from an early eradication campaign showed a fast expres- sion of phenotypic plasticity and
\end{abstract}


acquired larger sizes than those of the source population, probably due to a high prey availability and predator scarcity. The species is thriving at the expense of a small variety of native and non-native prey, but

the predation pressure on the endemic Podarcis pityusensis, the only native reptile in the island, is very high, as this lizard represents $56 \%$ of the prey in frequency, which might threaten its survival on the long term. Our results on the feeding ecology of the snake are of sufficient concern to justify the main- tenance of actions to eradicate this invader.

Keywords Balearic islands $\cdot$ Hemorrhois hippocrepis $\cdot$ Invasive species $\cdot$ Snake $\cdot$ Lizard

\section{Introduction}

Introduction and establishment of alien invasive species is one of the major threats to biodiversity on a global scale (Brooks et al. 2006). Island ecosystems are among the most vulnerable to invasive species, mainly due to the intrinsic traits of their native biota. Species that have evolved for a long time in islands are usually unsuccessful competing and avoiding be- ing predated by newcomers and are also more vulnerable to parasites brought by invaders (Whittaker and FernándezPalacios 2007; Simberloff et al. 2013). The Balearics have been isolated from the continent for 5.33 million of years, and its biota has evolved to adapt to these insularity conditions and experienced natural extinction processes during the PlioPleistocene (Bover et al. 2008) and human-mediated ones by the end of the third millennium BCE, when humans colonized the islands, and alien species introductions started (Pinya and Carretero 2011). Some of these introductions, like that accom- plished by two mammals, Martes martes and Mustela nivalis, together with an introduced snake, Macroprotodon cucullatus, have been considered responsible for the extinction of the native lizard Podarcis lilfordi in the main islands (Mallorca and Menorca; Alcover et al. 1981). The ability of reptiles as invaders is due in part to their biological characteristics: as ectotherms, a low metabolic rate allows them to survive in the absence of trophic resources during transportation; their secre- tive behavior makes them undetected during the first stages of the introductions; and they are able to show a rapid ecological niche shift when facing a new environment (Carretero 2004; Kraus 2009).

Within reptiles, snakes are a good example of harmful in- vasive species in islands, often having devastating impacts on native fauna (Martínez-Morales and Cuaron 1999; Guicking et al. 2006; Monzón-Argüello et al. 2015). Until quite recent- ly, all except two of the 63 Mediterranean islands larger than $75 \mathrm{~km}^{2}$ harbored at least one snake species, in most cases introduced; the exception were the westernmost Balearic islands, also called the Pityusic islands, Ibiza, and 
Formentera, which were never colonized by snakes (J.A. Mateo, com. per.), offering for these reptiles an empty niche scenario. Pliny the Elder realized this, when two thousand years ago he wrote "Ebusi, terra serpentes fugat", stating that Ibiza was free of snakes and that these could not thrive there; nowadays, it can be stated that he was wrong. In between 12 and 13 years, three species of snakes (Hemorrhois hippocrepis, Rhinechis scalaris, and Malpolon monspessulanus) were introduced in Ibiza by accident, transported from southern Iberian Peninsula within old orna- mental olive trees, and apparently in high numbers (Mateo et al. 2011). However, there have not been any records of M. monspessulanus in Ibiza during the last 6 years, and R. scalaris has been captured in a low rate which might mean that the first species failed in establishing and disappeared, while the second does not seem to have adapted well. But this is not the case of H. hippocrepis, which is expanding in Ibiza (Montes et al. 2015).

H. hippocrepis is a rather large-sized, slender-bodied, and long-tailed colubrid; it is distributed throughout the Western Mediterranean, being present in the southern two thirds of the Iberian Peninsula, northwestern Africa, and islands of Pantelleria, Sardinia, and Zembra, where it was also intro- duced (Pleguezuelos and Feriche 2014). In 2003, the species was reported for the first time in Ibiza, a rather topographical homogeneous island, where climate matches that of the source areas of the species, and where since then it has been repeat- edly introduced by human assistance (Mateo et al. 2011), be- ing these all the circumstances that predict a high spread rate of alien herpetofauna (Liu et al. 2014). It is thermophilic, rupicolous, and a frequent species in the thermomediterranean and mesomediterranean bioclimatic regions, where it thrives in open and sunny spaces with bare rocks and scrub forma- tions, besides human constructions, which are often used as habitat and shelter. It is an active forager that feeds almost exclusively on vertebrates (Pleguezuelos and Moreno 1990), thus representing a main threat to the native island vertebrates. Ibiza's ecosystems host some unique endemisms that could be suitable preys for the newcomer, like pulls of the Balearic

shearwater (Puffinus mauritanicus), the Balearic warbler (Sylvia balearica), and the most iconic one, the Ibiza wall lizard, Podarcis pityusensis. This lizard ranges through the main island and 39 of the islets surrounding it, most of them housing distinct subspecies, and have introduced populations in another Balearic island and in the Iberian Peninsula (Salvador 2014). Aside its intrinsic, biological value, this en- demism has an economic and social value for the island. Being the only native reptile, it is very popular and became a symbol that appears contoured in any signal or pamphlet referring to the biodiversity of the island. Besides this, it is also highly present in its tourism, the main income for the island (on clothing, jewelry, restaurants, hotels, paintings, sculptures ...), and in its culture (Pérez-Mellado 2009). 
Ecological niche models show current low habitat suitabil- ity in the Balearics for H. hippocrepis, with predictions for high suitability in Ibiza, in most climate change scenarios, by 2080 (Silva-Rocha et al. 2015); however, the species is perfectly thriving currently in Ibiza, and preliminary data show a fast spreading and large body size of individuals (Montes et al.2015). These are signs of a good feeding and low mortality rate in Ibiza, given the absence of almost any natural predators, the latter being named the enemy release hypothesis (Liu and Stiling 2006). Because of evidences on the rapid range expansion of the introduced snake and the potential risk posed for the native fauna, in 2014, the Island Administration begun an eradication program mostly based on trapping (Montes et al. 2015).

Improved understanding of the characteristics of successful invaders is necessary in order to counteract invasions and their negative impacts on ecosystems and develop management strategies (Liu et al. 2014). Diet studies on invasive species can shed light not only on applied aspects of its invasion success and effects on the native biota but also on evolutionary issues like local adaption and plasticity (Almeida et al. 2012; Riofrío-Lazo and Paez-Rosas 2015). We use the specimens afforded by the eradication program to analyze the diet habits of the $\mathrm{H}$. hippocrepis introduced in the Ibiza island and com- pare these and other ecological traits of this population with conspecifics from the source population (southern Iberian Peninsula), with another native population (northwestern Africa), and with two populations introduced in other Mediterranean islands (Sardinia, Pantelleria). The main goal is to seek for the negative impact on Ibiza's biota, particularly on some endemic species like the lizard P. pityusensis. As comparisons of prey composition between the Ibiza popula- tion of $\mathrm{H}$. hippocrepis and other native or introduced popula- tions will simply reflect variation in prey availability (MonzónArguiello et al. 2015), we also seek for the variation of other measures commonly used in feeding ecology, indica- tors of the success of this species as alien invader in the island. Thus, we also investigated (i) the trophic diversity, under the hypothesis that in this introduced population it must be low,considering the usual reduced richness of potential preys in islands (Whittaker and Fernández-Palacios 2007); (ii) the snake and prey size, under the hypothesis that the large body size of introduced snakes (Montes et al. 2015) is favored by feeding on larger preys (Boback 2003), based on the rule that relates predator and prey size in ophidians (Arnold 1993); and (iii) the feeding rate and body condition, under the hypothesis that introduced individuals feed more frequently and are in better body condition than the ones in their native areas, given the naïve prey presence (Paolucci et al. 2013).

\section{Methods}


Ibiza, with $572 \mathrm{~km}^{2}$ of area and $475 \mathrm{~m}$ asl of maximum alti- tude, is the largest of the Pityusic islands and exhibits a mean annual temperature of $17.9^{\circ} \mathrm{C}$, and the average yearly rainfall is $413 \mathrm{~mm}$ (Ibiza Airport weather station, $38^{\circ} 52^{\prime} 22^{\prime \prime}$ ' $\mathrm{N}$, $1^{\circ} 22^{\prime} 23^{\prime \prime} \mathrm{E}$; www.aemet.es). The landscape is characterized by a mosaic of two habitats, pine forests (Pinus halepensis) and cultivated land (orchards, cereal crops), with scattered patches of garrigue (Quercus coccifera, Juniperus phoenicea).

The individuals for this study come from the entire area invaded by the species, an area of $148 \mathrm{~km}^{2}$ in the northeastern quarter of the Ibiza island $\left(38^{\circ} 58^{\prime}-39^{\circ} 05^{\prime}\right.$ $\mathrm{N}, 39^{\circ} 2^{\prime}-39^{\circ} 4^{\prime} \mathrm{E}$; range in Ayllón 2015), and were captured during the 20132015 period by the Island Administration staff during eradica- tion campaigns (details in Montes et al. 2015). Specimens were sacrificed in a veterinary facility within the island (except 18 roadkills) and preserved in ethanol in the collection of the Granada University. In total, 293 specimens (142 males, 118 females, 33 immature) were examined. Before fixation and preservation, snout-vent length $(\mathrm{SVL})$ was measured to the nearest millimeter and biomass to the nearest $0.1 \mathrm{~g}$. Gut con- tents were checked by making a mid-ventral incision and prey items were identified to the species level. Some micromammals were identified by their hair remains according to Teerink (2004), under magnification $(\times 400)$. Only prey in good conditions were measured (SVL, $\pm 1 \mathrm{~mm})$ and weighed $( \pm 0.1 \mathrm{~g})$, after draining them on paper towel. Weight of partial- ly digested prey was estimated by comparison with conspe- cifics from the study area and from the bibliography (Gosàlbez 1987), considering this trait at the time of ingestion. While most prey remains were accurately measured for body length, body weight had to be inferred for many of them; for this reason, prey body length was used in comparisons.

The diet of H. hippocrepis is rather well known through its range, both for native (southern Spain and northern Morocco; details in Pleguezuelos and Moreno 1990; Pleguezuelos and Fahd 2004) and island-introduced populations (southern Sardinia and Pantelleria; details in Luiselli et al. 2012; Cattaneo 2015), favoring comparisons. To test if there was a difference in feeding frequency (the frequency of individuals

having gut content) between pairs of locations, we used the Pearson chi-squared test. Prey frequency of the snakes was compared among all regions and between pairs of regions by the same test, using only animals with gut content. To compare the diet of $\mathrm{H}$. hippocrepis among the five regions with quantitative data, and because of statistical constraints, we reduced the number of prey types to four: (i) lizards, (ii) small micrommamals (below Rattus size), (iii) large micromammals (Rattus size and above), and (iv) other prey (other reptiles, amphibians, birds, invertebrates; Table 1). Food-niche breadth was calculated according to Shannon's index; to calculate this index, specimens without gut contents or with unidentified 
prey were not considered. Absolute snake and prey size (SVL, weight) were compared between populations (the source one in southern Spain and the introduced one in Ibiza) by t test and M-WU test and prey size relative to snake size by ANCOVA, after testing for the homocedasticity of variances.

Body condition (the relationship between body mass and body length) is considered as an accurate indicator of foraging success in snakes (Bonnet et al. 2001). The body mass vari- ability is influenced by fat-body reserve (Bonnet et al. 2003); thus, we estimated body condition according to the impor- tance of fat bodies (Waye and Mason 2008). Because we were not able to accurately weigh fat bodies from some road-killed specimens, we scored fat body level of the $\mathrm{H}$. hippocrepis from Ibiza in five visual categories: zero, no traces of fat; one, small traces of fat among intestine loops; two, fat bodies covering less than half of the intestinal surface; three, fat bod- ies covering more than half of the intestinal surface; and four, a continuous fat layer in the ventral zone of the abdominal cavity. This procedure was already followed for the source population (Pleguezuelos and Feriche 1999) thus, enabling direct comparisons. Fat-body reserves in snakes tend to exhib- it ontogenetic, sexual, and seasonal shifts (Santos and Llorente 2004); we minimize the variability of data by comparing this trait according to sex, only for adult specimens (SVL > $500 \mathrm{~mm}$ in males and SVL > $680 \mathrm{~mm}$ in females; Pleguezuelos and Feriche 1999), and only for the springsummer seasons. Since body size in reptiles can vary with altitude, introduced source area comparisons have only con- sidered data (SVL, body weight, fat-body level) from source area (S Spain) specimens collected below $475 \mathrm{~m}$ asl, the maximum altitude of the Ibiza island. However, because of the little sexual size dimorphism and the lack of sexual differences in diet for the source population (Pleguezuelos and Feriche 2014), we did not take into account the sex of the individuals in the diet analysis. Correlation between snake body length and prey body length was fitted to the best regression type. Distributions of data were checked for normality prior to anal- yses, and in this article, mean values are followed by \pm one standard deviation with alpha set at 0.05 . All comparisons in multiple tests were significant after the Bonferroni correction.

Table 1 Data on feeding ecology of five populations of Hemorrhois hippocrepis from the Western Mediterranean. Prey types have been reduced to four operational groups to avoid zero cases. In the Ibiza population, small micromammals were 12 Apodemus sylvaticus, eight Mus sp., and four undetermined micromammals; all large micromammals were Rattus rattus; all lizards were Podarcis

pityusensis; other prey were five Tarentola mauritanica, one Hemidactylus turcicus, and one Turdus merula nestlings. For a detailed composition of the diet of the other populations view the sources (Pleguezuelos \& Moreno, 1990; Pleguezuelos \& Fahd, 2004; Luiselli et al., 2012; Cattaneo, 2015). Trophic diversity (Shannon index) was 


\section{Results}

Only seven prey species appeared in the diet of H. hippocrepis in Ibiza, 63.4\% were reptiles $(55.4 \% \mathrm{P}$. pityusensis, $6.7 \%$ Tarentola mauritanica, $1.3 \%$ Hemidactylus turcicus), $35.1 \%$ were mammals (16.2\% Apodemus sylvaticus, $10.8 \%$ Mus sp., 2.7\% Rattus rattus, 5.4\% unidentified micromammals), and one prey was a bird (1.3\% Turdus merula pulls; Table 1); thus, $56.7 \%$ of prey were native to Ibiza (P. pityusensis and T. merula). When prey mass was considered, the importance of mammals plus birds as prey increased (74.4\%).

There was a geographic shift in diet $\left(4 \times 5\right.$ table, $\chi^{2}=134.26, \mathrm{p}<0.0001$; Table 1$)$; the composition of the diet of the Ibiza population differed from that of all other popula- tions $\left(2 \times 4\right.$ table, $\chi^{2}$ test, $p<0.0001$ in all comparisons between Ibiza and other regions), particularly in that there was an excess of lizards with respect to the continental plus Sardinian populations $\left(2 \times 2\right.$ table, $\chi^{2}$ test, $p<0.0001$ in the three comparisons), and only the Pantelleria population did not significantly differ from the Ibiza population in the rate of lizard consumption $\left(2 \times 2\right.$ table, $\chi^{2}=1.78, \mathrm{p}=$ 0.18 ). As a consequence of the dominance of $P$. pityusensis in the diet, trophic diversity for the Ibiza population was the lowest, de- spite the sample size for this island was much larger than for the other regions (Table 1). For the Sardinian population, prey-type number and diversity index were probably infrascored, because 13 prey items were determined at the coarse level of "bird" prey type. In general, trophic diversity was lower in island populations with respect to mainland ones (Table 1).

Prey size of H. hippocrepis from Ibiza, as measured by prey SVL, averaged $62.6 \pm$ $23.0 \mathrm{~mm}(\mathrm{n}=47)$ and ranged from $22.8 \mathrm{~mm}(\mathrm{H}$. turcicus) to $150.0 \mathrm{~mm}$ (R. rattus). It was larger than the prey size of the native population of southern Spain (from the raw data in Pleguezuelos and Moreno [1990];

$\mathrm{t}=3.33$, d.f. $=136, \mathrm{p}=0.0017)$. However, Ibiza individuals did not predate significantly on relatively larger prey (ANCOVA, with prey SVL as dependent variable, snake SVL as covariate and region as grouping factor; $\mathrm{F}_{1,134}=2.80, \mathrm{p}=$ 0.09 ; Levene's test for homogeneity of variances, $p=0.147$ ). There was a positive relationship be- tween snake body length and prey body length for the Ibiza's population $(r=0.630, n=47, p<0.0001)$, although an onto- genetic shift in prey type hardly appeared, as the main prey, $\mathrm{P}$. pityusensis, was preyed by snakes of a wide spectrum of body size; the biggest prey, R. rattus, was preyed by the largest snakes (Fig. 1).

Fig.1 Prey size relative to snake size(expressed as snout-ventlength in both variables) for the population of Hemorrhois hippocrepis introduced in the Ibiza island. The best fitting for the data was to an exponential regression. Different symbols correspond to different prey types: Podarcis pityusensis (circle), Hemidactylus turcicus (cross), Tarentola mauritanica (star), Mus sp. 
(diamond), Apodemus sylvaticus (square), Turdus merula pulls (dash), Rattus rattus (triangle)

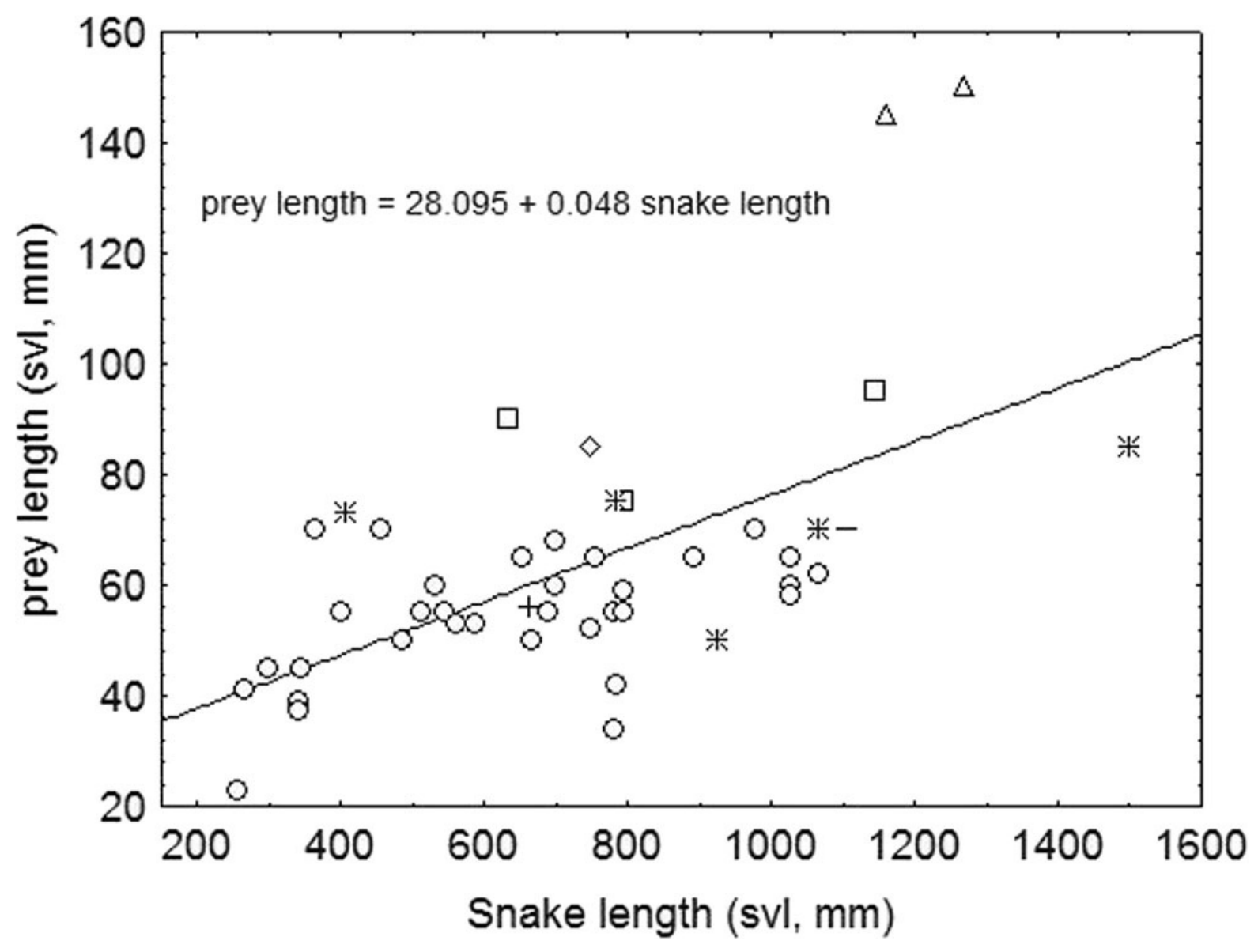

Body size of individuals of $\mathrm{H}$. hippocrepis from Ibiza was larger than that of individuals from the source region (southern Spain) as measured by SVL (mean = $712.8 \pm 238.8 \mathrm{~mm}, \mathrm{n}=290$, vsmean $=640.5 \pm 261.3 \mathrm{~mm}, \mathrm{n}=144 ; \mathrm{t}=2.87$, d.f. $=432, \mathrm{p}=$ 0.004 ) and as measured by body weight (mean

$=143.8 \pm 165.7 \mathrm{~g}, \mathrm{n}=262, \mathrm{vs} 103.7 \pm 165.7 \mathrm{~g}, \mathrm{n}=69 ; \mathrm{M}-\mathrm{WU}$ test $, \mathrm{Z}=2.16, \mathrm{p}=0.030$ ).

Feeding frequency of Ibiza individuals was rather low, and below that showed by other populations of the species, either native and introduced $\left(2 \times 2\right.$ table, $\chi^{2}$ test, $p$ $<0.007$ in all paired comparisons including Ibiza population; Table 1).

Body condition of adult Ibiza individuals, measured by fat body level, was higher than in individuals from southern Spain (from the raw data in Pleguezuelos and Feriche [1999]), either in males (mean $=3.49 \pm 0.79, \mathrm{n}=119$ vs mean $=2.22 \pm 1.24, \mathrm{n}=59 ; \mathrm{M}-\mathrm{WUtest}, \mathrm{Z}=6.41, \mathrm{p}=0.0001)$ or females $($ mean $=2.93 \pm 1.21, \mathrm{n}$ $=49$ vs mean $=2.11 \pm 1.25, \mathrm{n}=36 ; \mathrm{M}-\mathrm{WU}$ test $, \mathrm{Z}=2.85, \mathrm{p}=0.003)$. 


\section{Discussion}

The most commonly considered ecological impact from alien species is predation on sensitive native species (Kraus 2009). Analysis of the dietary habits of $\mathrm{H}$. hippocrepis in Ibiza has confirmed a strong predation on the endemic lizard P. pityusensis, which makes up the largest proportion of prey. This is a concerning result for the integrity of the native and endemic fauna of the rather small Ibiza island. P. pityusensis is the only endemic vertebrate in Ibiza, and its sibling species, P. lilfordi, disappeared from the two largest Balearic islands (Mallorca and Menorca) by predation of other introduced spe- cies (Bover et al. 2008; Pinya and Carretero 2011). Indeed, reptiles are not only among the most introduced vertebrate group in Mediterranean islands but also among the most af- fected by introduction of other reptiles (Kraus 2009). The secondary prey for H. hippocrepis in Ibiza in frequency, but primary in biomass, are micromammals (A. sylvaticus, Mus sp., R. rattus), aliens in Ibiza, thus, of no conservation con- cern. However, these aliens, of early arrival and high repro- ductive rate, are providing food resources for later aliens, like $\mathrm{H}$. hippocrepis, in a process named invasional meltdown (Simberloff and Vonn Holle 1999), probably with synergic and badly effects on the native prey, in this case, P. pityusensis.

H. hippocrepis is a rather generalist in diet where the spe- cies is native (Pleguezuelos and Fahd 2004). The low diet diversity showed by the Ibiza newcomer individuals would be the consequence of the low prey-type richness for this snake in that island. Although this might seem obvious at first hand, and in accordance with MacArthur's theory of island biogeography (where diet diversity is expected to be lower on islands than on mainland), the present literature provides both according (Alivizatos et al.2005) and conflicting cases (Clevenger 1993) with it. However, its diet in the study area was not only reduced in terms of prey type but was also more

dependent on lizards than any mainland native population (Pleguezuelos and Moreno 1990; Pleguezuelos and Fahd 2004) and other island-introduced populations, like Sardinia (Corti et al. 2000; Luiselli et al. 2012). Only conspecifics from another small island, Pantelleria, included many lizards in their diet (Cattaneo 2015), although the case in that island is not much comparable, since there the snake is feeding on an alien and invasive lizard, Podarcis sicula (Capula 1994). We confirm our hypothesis on the low trophic diversity of that population and suggest that the feeding habits of $\mathrm{H}$. hippocrepis from Ibiza reflect the high availability for this snake of a yet abundant and naïve prey: the endemic lizard P. pityusensis that evolved in a snake-free island during the Pleistocene (Bover et al. 2008). The fall of this symbol would not only mean a huge loss for the island's natural and cultural heritage but could also trigger negative cascading effects on some plant populations/species that depend on it (Pérez- Méndez et al. 
2016), as the lizard provides an important role as seed disperser (Riera et al. 2002). As in many other cases (Close et al. 2002; Garibaldi and Turner 2004), the embrace- ment of this symbol by the local communities might be the key to its conservation and the control/eradication of the aliens.

We also confirmed that $\mathrm{H}$. hippocrepis individuals from Ibiza are larger than the native ones from southern Spain, the source population. Contrasted body size has been widely recorded be- tween conspecific snake populations in mainland and islands (Shine 1987; Boback 2003; Aubret et al. 2004). Nearby to our study area, R. scalaris introduced in the islands of the Mediterranean coast of France showed large body size (Cheylan and Guillaume 1993), just like M. cucullatus intro- duced in the other Balearic Islands (Salvador 2014), or H. hippocrepis in Pantelleria (Cattaneo 2015). Large body size (in some cases gigantism) is one type of island syndrome (Pafilis et al. 2011). But the most striking fact of this case study is that in Ibiza's H. hippocrepis, this phenotypic change has occurred in a very short period, as the species was introduced in the island only 13 years ago, providing an impressive example of the fast rate at which phenotypic plasticity can take place after the inva- sion of a novel habitat (within ecological time scale; Herrel et al. 2008). Certainly, islands provide unusual environmental condi- tions that trigger rapid phenotypic (and evolutionary) changes in snakes (Aubret 2015; Luiselli et al. 2015).

Variation in snake body size between mainland and island populations has been interpreted as a consequence of differ- ences in prey abundance and/or prey size between both envi- ronments (Boback 2003). Higher prey abundance in the islands would be translated in a higher feeding success of snakes, and their concomitant effect on the body condition of individuals (Bonnet et al. 2001), and the same applies when aliens ingest larger prey (Boback 2003). Indeed, individuals from Ibiza showed a higher body size and level of abdominal fat bodies when compared to the mainland populations (Pleguezuelos and Feriche 1999; Montes et al. 2015). However, conflicting results were also found, as in Ibiza there were few individuals with gut content. Moreover, although there was a difference in prey size between Ibiza alien and southern Spain native snakes, this difference was rather the result of larger body size of Ibiza snakes, as there was no difference in relative prey size between both populations. The average prey size for the Ibiza snakes is mediated by the high frequency on the diet of a rather small prey, the lizard P. pityusensis. Accordingly, our results do not support the hypothesis that the large body size of introduced $\mathrm{H}$. hippocrepis is the consequence of the availability of largest prey in the island (Boback 2003).

Thus, if the large body size and good body condition of Ibiza's H. hippocrepis do not rely on the largest size of their prey, we suggest that our results on the feeding frequency are misleading. In ectotherms, the physiological response to feed- ing 
varies dramatically among organisms due mainly to the effects of meal size and body temperature (Secor 2003, Wang et al.2003). Smaller meals are digested faster than larger ones (Secor and Diamond 1997), and we suggest that we found relatively few fed snakes in Ibiza because they ingest rather small and slenderbodied prey, like P. pityusensis, of fast di- gestion. In ectotherms, higher body temperatures elevate met- abolic rates and shorten the time of the passage of ingesta through the gut (Lillywhite et al. 2002), probably the case of $\mathrm{H}$. hippocrepis in Ibiza, distributed in lowlands, where the temperature is warm (Guijarro 2002), providing a suitable thermal envelope for this thermophylous snake. Moreover, among snakes, gracile species are also characterized by short time of passage of the ingesta (Lillywhite et al. 2002), and H. hippocrepis is a slender-bodied snake. To support this state- ment, three anecdotal records have been obtained of only 55- $60 \mathrm{~h}$ for the gut passage of a lab mouse, in two average sized snakes kept in an outdoor enclosure in Ibiza (unpublished results).

There is an alternative hypothesis behind the larger body size and high abdominal fat level of individuals from Ibiza. Despite the lack of quantitative data on predation pressure on this snake in the island, only two of the seven predators iden- tified for the species in southern Spain are in the island (Falco tinnunculus and feral Felis silvestris; Pleguezuelos and Feriche 2014). Moreover, almost all the individuals from Ibiza have shown tail integrity and are devoid of other body scars, these circumstances being proposed as parameters for measuring predation risk in snakes (Santos et al. 2011). Suitability of the host region for aliens may be increased by the absence of predators (Kraus 2009). The paucity of the predator community and the scarcity of signals of (failed) predation events, suggest a scenario of predation release (Liu and Stiling 2006), which would favor longevity and large body size of $\mathrm{H}$. hippocrepis, turning the snake into a nutrient sink in the island (Greenlees et al. 2006).

After the analysis of diet habits, body size, and body con- dition, we conclude that the population of $\mathrm{H}$. hippocrepsis recently introduced in the Ibiza island threatens its biodiversi- ty. The snake relies on the abundance and/or easy predation of the island, naïve, primary prey (P. pityusensis), threatening the conservation of this endemic lizard. Moreover, the threat would be much more acute for the lizard subspecies in the surrounding islets, all nearby the main island (within $5 \mathrm{~km}$ from coastline, $1.17 \mathrm{~km}$ on average), and most maintaining a small population of lizards (29 ssp. have been described; Salvador 2014); if the alien snake arrives to any of them, it would lead to the extinction of a unique evolutionary unit, because of the lack of alternative prey. This possibility is real, as the snake has been observed in the sea swimming at least five times, and a shed has been obtained from one islet (un- published results). Our results warrant the current eradication measures as well as the improvement of resources invested in these (Montes et al. 2015). Because of evidences here afforded, we also suggest a regular census of the lizard, 
as an alternative method to monitor the impact of predation (Monzón-Argüello et al. 2015).

Acknowledgements Many people helped in the field and laboratory, like M. Feriche, E. Alaminos, J. Azor, T. Alcover, and the people of the COFIB. X. Santos improved a first draft of this manuscript. Samples have been collected according to the permits issued by the Balearic Government (ESP 26/2014). This work was supported by the Ibiza Insular Council, Balearic Government (grant numbers 54/2013 and 21/ 2015-AGRICULTURA).

\section{References}

Alcover JA, Moyà-Solà S, Moyà JP (1981) Les quimeres del passat: Els vertebrats fòssils del Plio-Quaternari de les Balears i Pitiüses. Moll, Palma de Mallorca

Alivizatos H, Goutner V, Zogaris S (2005) Contribution to the study of the diet of four owl species (Aves, Strigiformes) from mainland and island areas of Greece. Belg J Zool 135:109-118

Almeida D, Almodóvar A, Nicola GG, Elvira B, Grossman GD (2012) Trophic plasticity of invasive juvenile largemouth bass Micropterus salmoides in Iberian streams. Fish Res 113:153158. doi:10.1016/j. fishres.2011.11.002

Arnold SJ (1993) Foraging theory and prey size-predator size relations in snakes. In: Seigel RA, Collins JT (eds) Snakes: ecology and behav- ior. McGraw-Hill, New York, pp. 87-115

Aubret F (2015) Island colonization and the evolutionary rates of body size in insular neonate snakes. Heredity 115:349-356. doi:10.1038/hdy.2014.65

Aubret F, Maumelat S, Bradshaw D, Schwaner T, Bonnet X (2004) Diet divergence, jaw size and scale counts in two neighbouring popula- tions of tiger snakes (Notechis scutatus). Amph-Rep 25:9-17 doi:10.1163/156853804322992797

Ayllón E (2015) La culebra de herradura (Hemorrhois hippocrepis) en las islas Baleares. Bol Asoc Herpetol Esp 26:88-91

Boback SM (2003) Body size evolution in snakes: evidence from island populations. Copeia 2003:81-94. doi:10.1643/0045-8511(2003)003 [0081: BSEISE]2.0.CO;2

Bonnet X, Naulleau G, Lourdais O (2003) The benefits of complemen- tary techniques: using capture-recapture and physiological ap- proaches to understand costs of reproduction in the asp viper. In: Schuett GW, Hoggren M, Douglas ME, Greene HW (eds) Biology of the vipers. Eagle Mountain Publ, Utah, pp. 483-495

Bonnet X, Naulleau G, Shine R, Lourdais O (2001) Short-term versus long-term effects of food intake on reproductive output in a vivipa- rous snake, Vipera aspis. Oikos 92:297-308.

doi:10.1034/j.1600- 0706.2001.920212.x

Bover P, Quintana J, Alcover JA (2008) Three islands, three worlds: paleogeography and evolution of the vertebrate fauna from the Balearic islands. Quat Int 182:135-144. doi:10.1016/j. quaint.2007.06.039

Brooks TM, Mittermeier RA, da Fonseca GA, Gerlach J, Hoffmann M, Lamoreux JF, Rodrigues 
AS (2006) Global bio- diversity conservation priorities. Science 313(5783):58-61 .

doi:10.1126/science.1127609

Capula M (1994) Population genetics of a colonizing lizard: loss of var- iability in introduced populations of Podarcis sicula. Experientia 50: 691-696

Carretero MA (2004) From set menu to a la carte. Linking issues in trophic ecology of Mediterranean lacertids. Ital J Zool 71:121- 133. doi:10.1080/11250000409356621

Cattaneo A (2015) Contributo alla conoscenza dei serpenti delle isole del canale di Sicilia. Naturalista Siciliano S IV 34:3-28

Cheylan M, Guillaume CP (1993) Elaphe scalaris (Schinz, 1822) - Treppennatter. In: Böhme W (ed) Handbuch der Reptilien und Amphibien Europas. Band 3/I: Schlangen (Serpentes). AulaVerlag, Wiesbaden, pp. 397-429

Clevenger AP (1993) Pine marten (Martes martes Linné, 1758) compar- ative feeding ecology in an island and mainland population of Spain. Z Saugetierkd 58:212-212

Close DA, Fitzpatrick MS, Li HW (2002) The ecological and cultural importance of a species at risk of extinction, Pacific lamprey. Fisheries 27:19-25

Corti C, Luiselli L, Filippi E, Capula M (2000) Distribution, natural history and morphometrics of the critically endangered Coluber hippocrepis populations of Sardinia: a review, with additional data and conservation implications. Amphib-Reptil 21:279-287. doi:10.1163/156853800507471

Garibaldi A, Turner N (2004) Cultural keystone species: implications for ecological conservation and restoration. Ecol Soc 9(3):1. doi:10.2993/0278-0771-35.3.427

Gosàlbez J (1987) Insectívors i rosegadors de Catalunya. Ketres, Barcelona

Greenlees MJ, Brown GP, Webb JK, Phillips BL, Shine R (2006) Effects of an invasive anuran [the cane toad (Bufo marinus)] on the inver- tebrate fauna of a tropical Australian floodplain. Anim Conserv 9: 431-438. doi:10.1111/j.1469-1795.2006.00057.x

Guicking D, Griffiths RA, Moore RD, Joger U, Wink M (2006) Introduced alien or persecuted native? Resolving the origin of the viperine snake (Natrix maura) on Mallorca. Biodivers Conserv 15: 3045-3054. doi:10.1007/s10531-005-4878-y

Guijarro JA (2002) Valores horarios medios de temperatura y humedad relativa en Baleares. Bol Mens Climatol 57:121-134

Herrel A, Huygue K, Vanhooydonck B, Backeljau T, Breuguelmans K, Grbac I, Van Damme R, Irschick DJ (2008) Rapid large-scale evo- lutionary divergence in morphology and performance associated with exploitation of a different dietary resource. Proc Natl Acad Sci 105:4792-4795. doi:10.1073/pnas.0711998105

Kraus F (2009) Alien reptiles and amphibians: a scientific compendium and analysis. Springer, New York 
Lillywhite HB, de Delva P, Noonan BP (2002) Patterns of gut passage time and the chronic retention of fecal mass in viperid snakes. In: Schuett GW, Höggren M, Greene HW (eds) Biology of the vipers. Biological Sciences Press, Traverse City, pp. 497-506

Liu H, Stiling P (2006) Testing the enemy release hypothesis: a re- view and meta-analysis. Biol Invasions 8:1535-1545. doi:10.1007/s10530-005-5845-y

Liu X, Li X, Liu Z, Tingley R, Kraus F, Guo Z, Li Y (2014) Congener diversity, topographic heterogeneity and human-assisted dispersal predict spread rates of alien herpetofauna at a global scale. Ecol Lett 17:821-829. doi:10.1111/ele.12286

Luiselli L, Capula M, Rugiero L, Salvi D, Akani GC (2012) Does inter- specific competition with a stronger competitor explains the rarity of an endangered snake on a Mediterranean island? Ecol Res 27:649- 655. doi:10.1007/s11284-012-0936-6

Luiselli L, Petrozzi F, Mebert K, Zuffi MA, Amori G (2015) Resource partitioning and dwarfism patterns between sympatric snakes in a micro-insular Mediterranean environment. Ecol Res 30:527-535. doi:10.1007/s11284-015-1250-x

Martínez-Morales MA, Cuaron AD (1999) Boa constrictor, an introduced predator threatening the endemic fauna on Cozumel Island, Mexico. Biodivers and Conserv 8:957-963. doi:10.1023/A:1008815004072

Mateo JA, Ayres C, López-Jurado LF (2011) Los anfíbios y reptiles naturalizados en España: Historia y evolución de una problemática creciente. Bol Asoc Herpetol Esp 22:1-41

Montes EM, Estarellas J, Ayllón E, Carretero MÁ, Feriche M, Hernández PL, Pleguezuelos JM (2015) Dades preliminars del projecte pilot de control de serps a l'illa d'Eivissa. Monogr Soc Hist Nat Balear 20: 443-452

Monzón-Argüello C, Patiño-Martínez C, Christiansen F, Gallo-Barneto R, Cabrera-Pérez MA, Peña-Estevez MA, López-Jurado LF, Lee P (2015) Snakes on an island: independent introductions have differ- ent potentials for invasion. Conserv Genet 16:1225-1241. doi:10.1007/s10592-015-0734-0

Pafilis P, Foufopoulos J, Sagonas K, Runemark A, Svensson E, Valakos ED (2011) Reproductive biology of insular reptiles: marine subsi- dies modulate expression of the island syndrome.

Copeia 2011:545- 552. doi:10.1643/CE-10-041

Paolucci EM, MacIsaac HJ, Ricciardi A (2013) Origin matters: alien consumers inflict greater damage on prey populations than do native consumers. Divers Distrib 19:988-995.

doi:10.1111/ddi.12073

Pérez-Mellado V (2009) Les Sargantanes de les Balears. Documenta Balear, S.L., Palma de Mallorca

Pérez-Méndez N, Jordano P, García C, Valido A (2016) The signatures of Anthropocene defaunation: cascading effects of the seed dispersal collapse. Sci Rep 6:24820.

doi:10.1038/srep24820

Pinya S, Carretero MÁ (2011) The Balearic herpetofauna: a species up- date and a review on the 
evidence. Acta Herpetol 6:59-80. doi:10.13128/Acta_Herpetol-9579

Pleguezuelos JM, Fahd S (2004) Body size, diet and reproductive ecolo- gy of Coluber hippocrepis in the Rif (northern Morocco). Amphib- Reptil 25:287-302

Pleguezuelos JM, Feriche M (1999) Reproductive ecology of the horse- shoe whip snake (Coluber hippocrepis) in the Iberian peninsula. J Herpetol 33:202-207

Pleguezuelos JM, Feriche M (2014) Hemorrhois hippocrepis (Linnaeus, 1758). In: Ramos MA (ed) Salvador A (coord) Fauna Iberica, vol. 10, MNCN, CSIC, Madrid, pp 722-738. doi: $10.1163 / 1568538041975099$

Pleguezuelos JM, Moreno M (1990) Alimentación de Coluber hippocrepis en el SE de la Península Ibérica. Amphib-Reptil 11: 325-337

Riera N, Traveset A, García O (2002) Breakage of mutualisms by exotic species: the case of Cneorum tricoccon L. in the Balearic islands (western Mediterranean Sea). J Biogeogr 29:713719. doi:10.1046/j.1365-2699.2002.00719.x

Riofrío-Lazo M, Páez-Rosas D (2015) Feeding habits of introduced black rats, Rattus rattus, in nesting colonies of Galapagos petrel on San

Cristóbal Island. Galapagos PLoS ONE. doi:10.1371/journal.

pone.0127901

Salvador A (coord.) (2014) Reptiles. Fauna Ibérica, vol. X. MNCN, CSIC, Madrid

Santos X, Feriche M, León R, Filippakopoulou A, Vidal-García M, Llorente GA, Pleguezuelos JM (2011) Tail breakage frequency as an indicator of predation risk for the aquatic snake Natrix maura. Amphib-Reptil 32:375-383

Santos X, Llorente GA (2004) Lipid dynamics in the viperine snake Natrix maura from the Ebro Delta. Oikos 105:132-140. doi:10.1163/017353711X587264

Secor SM (2003) Gastric function and its contribution to the postprandial metabolic response of the Burmese python Python molurus. J Exp Biol 206:1621-1630. doi:10.1242/jeb.00300

Secor SM, Diamond J (1997) Determinants of post-feeding metabolic response in Burmese pythons, Python molurus. Physiol Zool 70: 202-212. doi:10.2307/30164303

Shine R (1987) Ecological comparisons of island and mainland popula- tions of Australian tigersnakes (Notechis: Elapidae). Herpetol 43: 233-240

Silva-Rocha I, Salvi D, Sillero N, Mateo JA, Carretero MÁ (2015) Snakes on the Balearic islands: an invasion tale with

implications for native biodiversity conservation. PLoS One.

doi:10.1371/journal.pone.0121026Simberloff D, Von Holle B (1999) Positive interactions of nonindig- 
enous species: invasional meltdown? Biol Invasions 1:21-32.

doi:10.1023/A:1010086329619Simberloff D, Martin JL, Genovesi P, Maris V, Wardle DA, Aronson J,

Courchamp F, Galil B, García-Berthou E, Pascal M, Pysek P, Sousa R, Tabacchi E, Vilà M (2013) Impacts of biological invasions: what's what and the way forward. TREE 28:58-66

Teerink BJ (2004) Hair of West European mammals: atlas and identifica- tion key. Cambridge Univ Press, Cambridge

Wang T, Morten Z, Arvedsen S, Vedel-Smith C, Overgaard J (2003) Effects of temperature on the metabolic response to feeding in Python molurus. Comp Biochem Physiol A 133:519-527. doi:10.1016/S1095-6433(02)00250-7

Waye HL, Mason RT (2008) A combination of body condition measure- ments is more informative than conventional condition indices: tem- poral variation in body condition and corticosterone in brown tree snakes (Boiga irregularis). Gen Comp Endocr 155:607-612

Whittaker RJ, Fernández-Palacios JM (2007) Island Biogeography: Ecology, Evolution, and Conservation. Oxford Univ Press, Oxford 